\title{
The Effect of Green Marketing toward the Consumers Buying Interest of Starbucks Coffee Mediated By Brand Image
}

\author{
Livia Windiana $^{1^{*}}$, Ary Bakhtiar ${ }^{2}$, Via Rizky Kurniasih ${ }^{3}$, Shaila Basamah ${ }^{4}$ \\ Agribusiness Study Program, Faculty of Agriculture, Muhammadiyah Malang University, Jl. Raya \\ Tlogomas No. 246, Malang, East Java 65144
}

Received: 9 September 2019; Revised: 18 February 2020; Accepted: 26 February 2020

\begin{abstract}
Starbucks is a company applied to go green and concerned in the environment. Moreover, it is supported by the policy regarding the plastic cups minimalization and recycled materials used in Starbucks outlets. The objectives of the study are (1) To determine the effect of green marketing on Starbucks coffee brand image in Malang, (2) To determine the effect of brand image on buying interest in Starbuck Coffee in Malang. This research conducted at Starbucks Malang City Point and Starbucks Kota Araya in MarchJuly 2019. The object of the research was the brand image (X1) green marketing (X2) and buying interest (Y). The data were analyzed using qualitative descriptive analysis, reliability test analysis, and path analysis. The results were (1) Green Marketing had positive and significant effects on Brand Image in other words the better quality of Green Marketing impacted on Brand Image quality improvement Starbucks Outlets in Malang (2) Brand Image had positive and significant effects on buying interest, in another sense better Brand Image of Starbucks Outlets in Malang impacted on consumer buying interest enhancement.
\end{abstract}

Keywords: green marketing; product image; buying interest

\section{How to Cite:}

Windiana, L., Bakhtiar, A., Kurniasih, V. R., \& Basamah, S. (2020). The Effect of Green Marketing toward the Consumers Buying Interest of Starbucks Coffee Mediated By Brand Image. HABITAT, 31(1), 36-41. https://doi.org/10.21776/ub.habitat.2020.031.1.4

\section{Introduction}

Globalization has changed the lifestyle of traditional societies towards the modern society due to technological sophistication. Various ways that are practical and instant become the choice of modern society in various aspects of life (Riska, 2010). Currently, global warming becomes a hot issue because of the large number of plastic wastes that continue to increase and difficult to decompose. The number of plastic wastesis increasing because many companies namely supermarkets, minimarkets, restaurants, and coffee shops still provide free plastic bags in serving as well as serving food.

Public awareness of the global warming effects is starting to increase now, and consumers are starting to choose environmentally friendly products. The Green consumer is a term for conscious consumers who use environmentally

${ }^{*}$ Livia Windiana

E-mail:windianalivia@yahoo.co.id

Telp: +6281259131141 friendly products, while "green business" is a term for companies that are aware of and incorporate environmental elements in every activity of their company. One of the most important activities in a company is marketing (marketing), so the concept of marketing must also be environmentally friendly (green marketing).

According to Almuarief (2016), the concept of green marketing was introduced by Bell, Emeri, and Feldman since 1971. Based on the concept of green marketing, marketing has been misplaced, because of its limitation to satisfy the needs and desires of customers but ignore the interests of the community and environment in the long run. The social insight concept is needed to state that companies must determine, the desires and interests of the target market to provide the desired satisfaction more effectively and efficiently compared to the competitors through ways that maintain or improve the welfare of consumers (Kotler \& Keller, 2009: 66). 
Go Green is an effort to convert product packaging materials into materials that are more easily decomposed by the environment. Go Green has four general principles namely Reduce, Reuse, Recycle and Replace (Anonymous, 2013). Starbucks is one of the companies that applied go green and concerned in the environment. It is shown by the existence of the policies regarding the minimizing use of tumblers, recycling the tumblers used, and using recycling materials at Starbucks outlets. Starbucks is a popular coffee shop from the United States. One reason why people choose to buy coffee at Starbucks because of its image as the largest coffee shop company in the world. This research conducted to see the background of consumers choosing Starbucks coffee brands compared to other coffee brands, also to find out consumers' awareness of green-labeled products. The purposes of this study were (1) To determine the effect of green marketing on Starbucks coffee brand image in Malang (2) To determine the effect of brand image on buying interest in Starbuck Coffee in Malang. From this background, research on the Effect of Green Marketing on Consumer Interest in Starbucks Coffee Mediated by Brand Image needed to be carried out.

\section{Methodology}

The research was conducted at Starbucks Malang City Point and Starbucks Araya City because in Malang there were only two Starbucks Coffee Shops. The research was conducted from March to May 2019. The approach used was a qualitative descriptive approach with survey methods. The survey method was a critical observation or investigation to obtain good information about a problem in a particular area or location, or an extensive study that was patterned for obtaining information (Daniel, 2002). The research object explained what, who was the object of research, where, when the research was conducted (Husein Umar (2005: 303). According to SuharismiArikunto (2001: 5), the object of research was the scope of the subject matter in research. The object of this research was the brand image as an independent variable (X1), green marketing as an independent variable (X2). and buying interest as a dependent variable (Y). The sampling technique was purposive sampling or sampling-based on certain characteristics such as respondents made purchases at Starbucks at least 3. The number of samples in this study was determined based on the opinion of Hair (1995) finding that the appropriate sample size was between 100 to 200 .

\subsection{Data Analysis}

\subsubsection{Normality Test Analysis}

Path analysis requires data to be normally distributed to avoid bias in data analysis. Outlier data must be discarded because it caused bias in interpretation and affected other data. Outlier data was data that deviated far from other data. Data was said to be normal if the multivariate C.R (critical ratio) had a condition of -2.58 $<c . r<2.58$. (Mustafa \& Wijaya, 2013).

\subsubsection{Path Analysis}

Path analysis was an extension of multiple linear regression analysis. Path analysis was an analysis to examine the effect of mediating variables in this research. The results of the analysis test were used to compare which effect was greater between direct and indirect effects, and to draw a conclusion whether the presence of this mediating variable could be strengthened or weakened the independent influence on the dependent (Ghozali, 2008). Path analysis used path diagrams to represent problems in the form of images and determining structural equations that stated the relationships between variables in the path diagram. Path diagram could be used to calculate the direct and indirect effects of the independent variables on the dependent variable (Ghozali, 2008).

\section{Results and Discussions}

\subsection{The Characteristics of Respondents}

The research respondents consisted of customers who were classified as follows:

Table 1. The Characteristics of Respondents by Occupation

\begin{tabular}{|c|c|c|}
\hline Occupation & Amount & Percentage \\
\hline 1. Entrepreneur & 5 & 9 \\
\hline 2. Civil Servants (PNS) & 1 & 1 \\
\hline $\begin{array}{l}\text { 3. Students/University } \\
\text { Students }\end{array}$ & 49 & 67 \\
\hline 4. Private Employees & 12 & 16 \\
\hline 5. Others & 6 & 7 \\
\hline Total & 73 & 100 \\
\hline
\end{tabular}

Source: Primary Data Processed, 2019

Most visitors in Starbucks outlets were dominated by students, it was shown by the percentage obtained as much as $67 \%$. This indicated that the market segmentation targeted 
by Starbucks outlets was millennial. Besides being a convenient place for a casual discussion and chatting, Starbucks outlets also had the advantage of having a Green Marketing program that millennials quite interested in it. Supported by Mustain (201) that said most Starbucks visitors were students because the place is comfortable and conducive.

Table 2. The Characteristics of Respondents by Age

\begin{tabular}{llll}
\hline No. & \multicolumn{1}{c}{ Age } & \multicolumn{2}{c}{ Amount Percentage } \\
\hline 1. & $\begin{array}{l}\text { Teenagers }<20 \\
\text { years old }\end{array}$ & 18 & 24 \\
2. & $\begin{array}{l}\text { Teenagers 21-30 } \\
\text { years old }\end{array}$ & 55 & 75 \\
3. & $\begin{array}{l}\text { Adults in early } 31- \\
\text { 40 years }\end{array}$ & 8 & 10 \\
4. & Adults $>41$ tahun & 0 & 0 \\
\hline & Total & 73 & 100 \\
\hline
\end{tabular}

Source: Primary Data Processed, 2019

Based on the general classification of respondents by age, the respondents who were teenagers quite dominated as much as 75 percent. This was influenced by the comfortable atmosphere at the Starbucks outlets which was very comfortable for chatting. Moreover, varied promotions such as buy 2 get 1 free product at certain times influenced the costumers' buying decision. The result of this study also reinforced the statement that the majority of costumers in Starbucks outlets in Makasar were dominated by teenagers (21-25 years old).

Table 3. The Characteristics of Respondents by Income

\begin{tabular}{lllc}
\hline No. & \multicolumn{1}{c}{ Income } & \multicolumn{2}{c}{ Amount Percentage } \\
\hline 1. & $\begin{array}{l}\text { Less than Rp. } \\
1.500 .000\end{array}$ & 19 & 26 \\
2. & $\begin{array}{l}\text { Rp. } 1.500 .000-\text { Rp. } \\
3.000 .000\end{array}$ & 23 \\
3. & $\begin{array}{l}\text { Rp. } 3.000 .000-\text { Rp. } \\
\begin{array}{l}4.500 .000 \\
\text { More than Rp. }\end{array}\end{array}$ & 10 \\
4.500.000 & 29 & 39 \\
Total & 73 & 100 \\
\hline
\end{tabular}

Source: Primary Data Processed, 2019

Based on the amount of income received by respondents, the majority had income> Rp. $4,500,000$. This further clarified that the segmentation of Starbucks outlets was only for the upper-middle class. The same opinion stated by Mustain (2012) that the Starbucks visitors have quite a high-income category, ranging between Rp. 2,000,000 - Rp. 4,000,000. This was because the price of the products was quite high, so it only reached by high-income groups.

In the structural equation modeling of the PLS approach, several tests were performed, namely: (1) testing the structural model goodness of fit, (2) estimating the measurement model (outer model), (3) estimating the structural model (inner model), and (4) testing mediating effect.

\subsection{Goodness of Fit Model Structural Testing (Inner Model)}

The Goodness of Fit structural model tests on the inner model was using the predictiverelevance score $(\mathrm{Q} 2)$. The following results of the predictive-relevance (Q2) structural model calculations were as follows:

Table 4. Predictive Relevance Model Structural

\begin{tabular}{lll}
\hline $\begin{array}{l}\text { Variabel } \\
\text { Endogen }\end{array}$ & $\mathbf{R}^{\mathbf{2}}$ & $\mathbf{Q}^{\mathbf{2}}$ \\
\cline { 1 - 2 } $\mathrm{M}$ (Brand Image) & 0.446 & 0 \\
\cline { 1 - 2 } $\mathrm{Y}$ (Minat Beli) & 0.486 & \\
\hline $\mathrm{Q} 2 \quad=1-(1-\mathrm{R} 2)(1-\mathrm{R} 2) \ldots(1-\mathrm{R} 2)$ \\
$\begin{aligned} \mathrm{Q} 2 \quad & =1-(1-0.446)(1-0.486) \\
& =1-(0.554 \times 0.514) \\
& =1-0.284 \\
& =0.716\end{aligned}$
\end{tabular}

The results of the calculation showed a predictive-relevance score (Q2) of 0.716 or $71.6 \%$. A predictive relevance score of $71.6 \%$ indicated that the diversity of data that could be explained by the model was $72.5 \%$ or in other words, the information contained in the data $71.6 \%$ could be explained by the model. Meanwhile, the remaining $71.6 \%$ was explained by other variables (not yet contained in the model) and error.

\subsection{Outer Model Testing}

Based on the results of testing the structural model with the PLS method, the next step was to test the outer structural model on the indicators forming latent variables. The first step in testing the outer model was convergent validity on the indicators forming latent variables. This test was carried out to determine the validity level of the latent variables indicators. The individual indicators were considered valid if they had an outer loading score above 0.7 or a t-statistic score above 1.96 and a p-value of less than 0.05 . An outer loading value of 0.5 could still be considered to have a 
fairly good level of validity (Jogiyanto and Abdillah, 2009). Based on the output of SmartPLS, the convergent validity test results were as follows:

Table 5. Testing Convergent Validity of Research Variables

\begin{tabular}{|c|c|c|c|}
\hline Indicator & Variable & $\begin{array}{c}\text { Outer } \\
\text { Loading }\end{array}$ & $\begin{array}{c}\text { p- } \\
\text { value }\end{array}$ \\
\hline BI 1 & \multirow{6}{*}{$\begin{array}{l}\text { Brand Image } \\
\text { (M) }\end{array}$} & 0.749 & 0.000 \\
\hline BI 2 & & 0.787 & 0.000 \\
\hline BI 3 & & 0.734 & 0.000 \\
\hline BI 4 & & 0.818 & 0.000 \\
\hline BI 5 & & 0.775 & 0.000 \\
\hline BI 6 & & 0.555 & 0.000 \\
\hline GM 1 & \multirow{13}{*}{ Green } & 0.479 & 0.000 \\
\hline GM 2 & & 0.628 & 0.000 \\
\hline GM 3 & & 0.650 & 0.000 \\
\hline GM 4 & & 0.591 & 0.000 \\
\hline GM 5 & & 0.655 & 0.000 \\
\hline GM 6 & & 0.655 & 0.000 \\
\hline GM 7 & & 0.560 & 0.000 \\
\hline GM 8 & & 0.225 & 0.170 \\
\hline GM 9 & & 0.426 & 0.000 \\
\hline GM 10 & & 0.462 & 0.001 \\
\hline GM 11 & & 0.572 & 0.000 \\
\hline GM 12 & & 0.568 & 0.000 \\
\hline GM 13 & & 0.509 & 0.000 \\
\hline MB 1 & \multirow[b]{2}{*}{$\begin{array}{l}\text { Buying Interest } \\
\text { (Y) }\end{array}$} & 0.724 & 0.000 \\
\hline MB 2 & & 0.730 & 0.000 \\
\hline
\end{tabular}

Based on Table 5 regarding the outer loading of research variables, it could be explained that most indicators had an outer loading of more than 0.5 and a p-value of less than 0.05 . So, it could be said that most of the significant indicators and convergent validity of these variables had been fulfilled. Several indicators that had an outer loading of less than 0.5 and a p-value of more than 0.05 which indicated a low level of validity. These indicators included GM1, GM8, GM9, and GM10. Therefore, these indicators were deemed not to meet convergent validity and were eliminated for further analysis. In the Green Marketing (X) variable, GM5 and GM6 indicators had the greatest outer loading scores. This indicated that the biggest contribution to Green Marketing (X) was measured by GM5 and GM6. In the Brand Image (M) variable, BI2 had the largest outer loading score. This indicated that the biggest contribution to Brand Image (M) was measured by BI2. In the Buy Interest (Y) variable, MB4 had the largest outer loading score. This indicated that the largest contribution to Buy Interest (Y) was measured by MB4.

\subsection{Discriminant Validity Model Structural (Outer Model)}

After conducted the convergent validity testing on the indicators forming latent variables, the next step was testing the discriminant validity on the outer model. This test was carried out to measure the extent to which the indicators were able to explain the latent variables. Indicators were said to be able to explain the latent variable if it had a good correlation score for the latent variable. The discriminant validity of outer model testing was done by comparing cross-loading. It was expected that each indicator had a better loading score on the measured variable than the other variables (Ghozali, 2008).

Table 6. Discriminant Validity Outer Model Testing using Cross Loading

\begin{tabular}{cccl}
\hline Indikator & $\begin{array}{c}\text { Brand } \\
\text { Image } \\
(\mathbf{M})\end{array}$ & $\begin{array}{c}\text { Green } \\
\text { Marketing } \\
(\mathbf{X})\end{array}$ & $\begin{array}{l}\text { Minat } \\
\text { Beli }(\mathbf{Y})\end{array}$ \\
\hline BI_1 & $\mathbf{0 . 7 5 1}$ & 0.532 & 0.257 \\
\hline BI_2 & $\mathbf{0 . 7 8 9}$ & 0.535 & 0.265 \\
\hline BI_3 & $\mathbf{0 . 7 3 0}$ & 0.486 & 0.561 \\
\hline BI_4 & $\mathbf{0 . 8 1 3}$ & 0.585 & 0.616 \\
\hline BI_5 & $\mathbf{0 . 7 7 6}$ & 0.521 & 0.446 \\
\hline BI_6 & $\mathbf{0 . 5 6 2}$ & 0.386 & 0.295 \\
\hline GM_2 & 0.445 & $\mathbf{0 . 5 9 7}$ & 0.538 \\
\hline GM_3 & 0.376 & $\mathbf{0 . 6 5 9}$ & 0.339 \\
\hline GM_4 & 0.432 & $\mathbf{0 . 6 3 7}$ & 0.466 \\
\hline GM_5 & 0.551 & $\mathbf{0 . 7 1 6}$ & 0.413 \\
\hline GM_6 & 0.407 & $\mathbf{0 . 6 7 7}$ & 0.408 \\
\hline GM_7 & 0.329 & $\mathbf{0 . 5 3 2}$ & 0.280 \\
\hline GM_11 & 0.299 & $\mathbf{0 . 5 1 1}$ & 0.434 \\
\hline GM_12 & 0.492 & $\mathbf{0 . 5 9 3}$ & 0.335 \\
\hline GM_13 & 0.394 & $\mathbf{0 . 5 3 8}$ & 0.319 \\
\hline MB_1 & 0.323 & 0.394 & $\mathbf{0 . 7 2 3}$ \\
\hline MB_2 & 0.371 & 0.399 & $\mathbf{0 . 7 2 7}$ \\
\hline MB_3 & 0.542 & 0.518 & $\mathbf{0 . 7 4 3}$ \\
\hline MB_4 & 0.468 & 0.430 & $\mathbf{0 . 7 6 9}$ \\
\hline MB_5 & 0.399 & 0.398 & $\mathbf{0 . 7 4 2}$ \\
\hline MB_6 & 0.475 & 0.610 & $\mathbf{0 . 7 0 4}$ \\
\hline MB_7 & 0.240 & 0.376 & $\mathbf{0 . 5 9 7}$ \\
\hline MB_8 & 0.350 & 0.492 & $\mathbf{0 . 6 4 4}$ \\
\hline & & &
\end{tabular}


Testing the discriminant validity of the outer model using cross loading was presented in Table 6. Based on Table 6, it could be explained that each indicator had the greatest loading score on the variable it was measuring. The results of this test indicated that the discriminant validity of the outer model had been fulfilled.

\subsection{Composite Reliability Outer Model Testing}

After testing the convergent validity and discriminant validity, the internal consistency of the outer model must be tested further. The internal consistency testing of the outer structural models was done by calculating the composite reliability of each variant patent. The indicators said to have good internal consistency if the composite reliability in the latent variable was more than 0.6 (Ghozali, 2008).

Table 7. Composite Reliability Outer Model Testing

\begin{tabular}{ccc}
\hline Variable & $\begin{array}{c}\text { Cronbach's } \\
\text { Alpha }\end{array}$ & $\begin{array}{c}\text { Composite } \\
\text { Reliability }\end{array}$ \\
\hline M (Brand Image) & 0.834 & 0.879 \\
\hline X (Green Marketing) & 0.787 & 0.841 \\
\hline $\begin{array}{c}\text { Y (Buying } \\
\text { Interest) }\end{array}$ & 0.858 & 0.889 \\
\hline
\end{tabular}

Based on Table 7, it could be explained that the composite reliability of each variable varied more than 0.6 so that the testing could be concluded that the indicators of the compilation of variant variables had good internal consistency. Likewise, the Alpha Cronbach value for all variables was more than 0.6 which showed a high internal consistency.

\subsection{The Results of Structural Model Testing}

The results of testing the direct effect coefficient on each path were presented in Table 8.

Table 8. The Testing Results of Inner Model Influence

\begin{tabular}{ccc}
\hline Influence Path & $\begin{array}{c}\text { Coefficient } \\
\text { Path }\end{array}$ & p-value \\
\hline $\begin{array}{l}\text { X (Green Marketing) } \\
\text {-> M (Brand Image) }\end{array}$ & 0.690 & $0.000^{* *}$ \\
\hline $\begin{array}{l}\text { M (Brand Image) -> } \\
\text { Y (Buying Interest) }\end{array}$ & 0.238 & $0.035^{* *}$ \\
\hline $\begin{array}{c}\text { X (Green Marketing) } \\
\text {-> Y ( Buying } \\
\text { Interest) }\end{array}$ & 0.491 & $0.000^{* *}$ \\
\hline
\end{tabular}

Information:

** : Significant at 5\% error level

ts : Not Significant

The influence path between the Green Marketing (X) variable on Brand Image (M), showed that the Green Marketing (X) variable had a positive and significant effect on Brand Image (M). The better the quality of Green Marketing (X), it would give an impact on improving the quality of Brand Image (M) directly. This could strengthen the mission of the Starbucks outlets in conducting promotions to the consumers. This strategy made Starbucks outlets always had space in the hearts of its beloved customers. This strategy needed to be maintained in order to maintain the existence of Starbucks outlets in the future. In Indonesia, the campaigns against the use of plastic raw materials for food packaging products were constantly changing towards Go Green. The same opinion was also explained by Dief and Font (2010), who said that the efforts made by the hotel management in maintaining the brand image of the hotel would be far more significant with the Green Marketing method. Furthermore, comparing with the results of this study (Fernando, Shaharudin, et al. 2016), the marketing patterns on furniture with the concept of Green Marketing had a positive impact on increasing purchases and customer satisfaction. As a service company, the Starbucks outlets continuously made improvements to provide maximum services for the consumers. The company value that instilled in every Starbucks employee was to provide customer service first were at the forefront.

\section{Conclusions}

(1) Green Marketing has a positive and significant effect on Brand Image in other words, the better the Green Marketing of the Starbuck outlets in Malang will be seen on the quality improvement of the Brand image.

(2) The Brand Image has a positive and significant effect on Buying Interest, in other words, the better the Brand Image in The Starbucks outlets in Malang will be seen in the improvement of consumers' Buying Interest.

\section{Suggestions}

(1) Starbucks maintains and enhances environmentally friendly activities 
(2) Currently, Starbucks has not received coffee purchases using a tumbler that is not from Starbucks. It will be better if Starbucks receives coffee purchases using any tumbler, even though they do not get a promo.

\section{References}

Agustin, Risna Dwi, S. Kumadji, E. Yulianto. (2015). Pengaruh Green Marketing Terhadap Minat Beli serta Dampaknya pada Keputusan Pembelian. Jurnal Administrasi Bisnis (JAB), Vol.22, No.2, Hal.1-10.

Ambarwati, Miki dkk. (2015). Pengaruh Citra Merek Terhadap Minat Beli (Survei Pada Mahasiswa Universitas Brawijaya Yang Menggunakan Pasta Gigi Pepsodent). Jurnal Administrasi Bisnis (JAB), Vol.25, No.1,Hal.1-7.

Arikunto, Suharsimi. (1990). Manajemen Penelitian. Yogyakarta. Rineka Cipta.

Arista, E. Desi dan Sri Rahayu Tri Astuti. (2011). Analisis Pengaruh Iklan, Kepercayaan Merek dan Citra Merek terhadap Minat Beli Konsumen. Jurnal Aset, Vol.13, No.1, Hal.37-45.

Arseculeratne, Dinuk and Rashad Yazdanifard. (2014). How Green Marketing Can Create a Sustainable Competitive Advantage for a Business. International Business Research. 7: 130-137.

Azwar, S. (2009). Reliabilitas dan Validitas. Yogyakarta: Pustaka Pelajar.

Devi, P.I. Shinta. (2014). Pengaruh Green Marketing Terhadap Minat Beli Konsumen Pada Produk The Body Shop. Skripsi. Bandung: Universitas Kristen Maranatha.

Dief, M. E. and X. Font (2010). "The determinants of hotels' marketing managers' green marketing behaviour." Journal of Sustainable Tourism18(2): 157174.

Durianto,Darmadi,Sugiarto,ToniSitinjak. (2001). Strategi Menaklukkan Pasar Melalui Riset Ekuitas dan Perilaku Merek. Jakarta: PTGramediaPustakaUtama.

Ferdinand, Augusty. (2006). Metode Penelitian Manajemen. Edisi Kedua. Badan Penerbit UNDIP: Semarang.
Fernando, Y., et al. (2016). "Eco-innovation practices: a case study of green furniture manufacturers in Indonesia." International Journal of Services and Operations Management23(1): 43-58.

Grace, D and O'Cass, A. (2002). Brand Associations: Looking Through the Eye of the Beholder. Qualitive Market Research: An International Jurnal.(5)2:96- 111.

Ghozali, Imam. (2008). Model Persamaan Struktural Konsep dan Aplikasi dengan Program Amos 16.0. Badan Penerbit UNDIP: Semarang.

Hair, et al. (1995).Multivariate Data Analysis 6 $E d$. New Jersey: Pearson education

Mustain, H. L. (2012). "Analisis Pengaruh Strategi Positioning terhadap Keputusan Pembelian pada Konsumen Starbucks Coffee di Makassar." Skripsi. Fakultas Ekonomi dan Bisnis, Universitas Hasanuddin. Makassar. 